\title{
Two schemes for production of biosurfactant from Pseudomonas aeruginosa MR01: applying residues from soybean oil industry and silica sol-gel immobilized cells
}

Tayebe Bagheri Lotfabad*, National Institute of Genetic Engineering and Biotechnology (NIGEB), Department of Industrial and Environmental Biotechnology, Tehran, Iran. bagheril@nigeb.ac.ir

Negisa Ebadipour, National Institute of Genetic Engineering and Biotechnology (NIGEB), Department of Industrial and Environmental Biotechnology, Tehran, Iran. Nakisa_pl@yahoo.com

Reza Roostaazad, Sharif University of Technology, School of Chemical and Petroleum Engineering, Tehran, Iran. roosta@sharif.edu

Maryam Partovi , National Institute of Genetic Engineering and Biotechnology (NIGEB), Department of Industrial and Environmental Biotechnology, Tehran, Iran. maryam_partovi88@yahoo.com

Manochehr Bahmaei, Faculty of Chemistry, North Tehran Branch, Islamic Azad University, Tehran, Iran. mbahmaie@savola.com

*Corresponding author: Tayebe Bagheri Lotfabad (Ph.D.)

National Institute of Genetic Engineering and Biotechnology (NIGEB), Shahrak-e pajoohesh, km 15,Tehran-karaj Highway, Tehran,Iran, P.O.Box:14965/161.

E-mail: bagheril@nigeb.ac.ir

Tel: +982144787321

Fax: +982144787399 


\section{Abstract}

Rhamnolipids are the most common biosurfactants and $P$. aeruginosa strains are the most frequently studied microorganisms for the production of rhamnolipids. Eco-friendly advantages and promising applications of rhamnolipids in various industries are the major reasons for pursuing the economic production of these biosurfactants. This study shows that cultivation of P. aeruginosa MR01 in medium contained inexpensive soybean oil refinery wastes which exhibited similar levels and homologues of rhamnolipids. Mass spectrometry indicated that the Rha-C10-C10 and Rha-Rha-C10-C10 constitute the main rhamnolipids in different cultures of MR01 including one of oil carbon source analogues. Moreover, rhamnolipid mixtures extracted from different cultures showed critical micelle concentrations $(C M C)$ in the range of $\simeq 24$ to $\simeq 36 \mathrm{mg} / \mathrm{l}$ with capability to reduce the surface tension of aqueous solution from 72 to $\simeq 27-32$ $\mathrm{mN} / \mathrm{m}$. However, the sol-gel technique using tetraethyl orthosilicate (TEOS) was used as a gentler method in order to entrap the $P$. aeruginosa MR01 cells in mold silica gels. Immobilized cells can be utilized several times in consecutive fermentation batches as well as in flow fermentation processes. In this way, reusability of the cells may lead to a more economical fermentation process. Approximately $90 \%$ of cell viability was retained during the silica sol-gel immobilization and $\simeq 84 \%$ of viability of immobilized cells was preserved for 365 days of immobilization and storage of the cells in phosphate buffer at $4 \stackrel{\circ}{ } \mathrm{C}$ and $25 \circ \mathrm{C}$. Moreover, mold gels showed good mechanical stability during the seven successive fermentation batches and the entrapped cells were able to efficiently preserve their biosurfactant-producing potential.

Key Words: P. aeruginosa MR01, inexpensive wastes, silica sol-gel, immobilization, rhamnolipids, LC-MS 


\section{Introduction}

Biosurfactants are the biocompatible surface active molecules that are produced by several living cells, particularly by microorganisms. However, the high cost of biosurfactant production is the greatest deterrent for their use in large industries [1]. Therefore, any successful alteration, however small, may improve the efficiency and economy of process. The end production cost of a product is one of the determining factors for industry owners when making important production decisions. Provided that the cost of producing the biosurfactants becomes competitive with chemical surfactants, industries which deal with a mass consumption of surfactant for different processes may be persuaded to replace the biosurfactants and benefit from their eco-friendly and biocompatibility features. Saving on raw material costs is a traditional way to achieve reduced end costs.

Culture medium composition and living cells are the two mainstays for production of biological surfactants and therefore economic considerations in each case can improve production economics. In this regard, our previous studies dealt with the production of rhamnolipid type surfactants from waste carbon sources, i.e. soybean oil refinery wastes, by $P$. aeruginosa MR01 [2]. Similarly, the effect of fatty acid composition of wastes on rhamnolipid structure and surfactant activity of biosurfactants is also examined in the present work.

Moreover, the immobilization of $P$. aeruginosa MR01 is studied in order to improve reusability resulting in cost savings in biosurfactant production. Cell immobilization is considered the second technique for economical production due to the fact that there is no need to restock microorganism cells. Immobilization of microorganisms for industrial applications first described by Chibata et al [3] continues to be employed for different bioprocesses. High cell density, high stability, absence of cell washout and extended reaction times are some of the advantages of cell immobilization [4]. Immobilized bacteria can remain viable for a long period 
of time, appear resistant to harsh culture conditions and can be reused a number of times which makes cell immobilization a promising alternative for free cells in flow bioreactors [5]. The sol-gel technique has emerged as an interesting alternative among the numerous immobilization methods because it allows materials to be obtained with more desirable chemical and mechanical features [6,7]. In recent decades, sol-gel encapsulation techniques have been applied for the immobilization of bacteria [8], mammalian cells [9], biomolecules and enzymes [10] and other biological agents for different applications. Among different encapsulation materials, silica matrices have shown many advantageous traits such as high porosity, desired mechanical strength, high chemical and thermal stability $[11,12]$ as well as non-toxicity and eco-friendliness $[10,13]$. Moreover, the immobilization process in silica matrices involves neither high temperatures nor harsh chemical reactions. From the time Carturan et al. [14] first introduced the encapsulation of living microorganisms in sol-gel silica matrices, other researchers reported the extension of this process to other cell types $[15,16]$ such as bacteria, yeast, algae and mammalian cells. These were all successfully immobilized in silica matrices $[9,17-21]$.

However, the sol-gel technique often requires the use of tetramethyl orthosilicate (TMOS) or tetraethyl orthosilicate (TEOS) as precursors for synthesis of silica matrices causing accumulation of relatively high concentrations of alcohol that may be harmful for the biological activity of cells (growth, metabolic activity and enzymatic activity) [22,23]. In some cases, biocompatible additives such as glycerol, polyethylene glycol or glycine betaine were used to improve the cytocompatibility of the silica matrices for cell immobilizations [22,24-26]. However, Meunier et al. [15] summarized the considerable progress made in cell entrapment using silica matrixes and presented silica as a promising host for cell immobilization. 
In the present study, we examined the immobilization of Pseudomonas aeruginosa MR01 in sol-gel silica matrices and its application for biosurfactant production. This strain previously demonstrated good potential to produce biosurfactant under controlled conditions $[1,27,28]$ and, therefore, may be considered a suitable candidate for this purpose. Herein, silica gel matrixes were synthesized with TEOS as the precursor and used for entrapping the $P$. aeruginosa MR01 in the presence of high molar ratio of water to alkoxy silicate. Viability and surfactant-producing ability of bacterial cells are compared before and after immobilization.

\section{Materials and methods}

\subsection{Chemicals and feedstocks}

All chemicals were purchased from the companies Merck and Sigma and used without further purification. Reagent grade tetraethyl orthosilicate (TEOS: $\left.\mathrm{Si}\left(\mathrm{OC}_{2} \mathrm{H}_{5}\right)_{4}\right)$ was purchased from Sigma-Aldrich (Sigma-Aldrich Corp. St. Louis, $\mathrm{MO}, \mathrm{USA}$ ). $\mathrm{KH}_{2} \mathrm{PO}_{4}, \mathrm{MgSO}_{4}, \mathrm{NaNO}_{3}$, yeast extract, ethanol and glutaraldehyde were purchased from Merck Chemical Co. (Germany). The samples of refined soybean oil and refinement wastes including acid oil, deodorizer distillate and soapstock were provided by Behshahr Industrial Company.

\subsection{Microorganisms and culture conditions}

Pseudomonas aeruginosa strain MR01 (EU795302) was previously isolated from crude oil in Iran [27] and kept as glycerol stock cultures at $-80^{\circ} \mathrm{C}$. Bacterial inoculates were prepared by cultivation of bacteria cells in LB medium and incubated at $30^{\circ} \mathrm{C}$ and $200 \mathrm{rpm}$ overnight. Flasks (250-ml) containing SOM medium [29] including soybean oil 6\% (V/V) were used for biosurfactant production, using both free and immobilized cells. Cultures were incubated for $168 \mathrm{hr}$ at $30^{\circ} \mathrm{C}$ and $200 \mathrm{rpm}$. In order to study the effect of carbon sources on biosurfactant features, different experiments were carried out replacing the soybean oil in medium with acid oil 6\% (V/V), deodorizer distillate 6\% (V/V) or soapstock $8 \%(\mathrm{~V} / \mathrm{V})[2]$ 


\subsection{Cell immobilization in silica gel matrices}

The silica gel was prepared by the modified method of Alvarez et al [30]. A mixture of $1 \mathrm{ml}$ TEOS, $0.8 \mathrm{ml}$ distilled water and $0.06 \mathrm{ml} \mathrm{HCl}, 0.05 \mathrm{M}$, was prepared and sonicated for $20 \mathrm{~min}$ at room temperature to reach a homogenous solution. In order to get a fully hydrolyzed sol solution, $1.5 \mathrm{ml}$ distilled water was added to the homogenized solution and ethanol was removed by evaporation at $45^{\circ} \mathrm{C}$ for $10 \mathrm{~min}$. Moreover, a high molar ratio of water to alkoxy silicate was used to help negate the harmful effect of ethanol on encapsulated cells since the high amount of water in the sol helped dilute the released alcohol, ensuring the biocompatibility of the process [9].

In order to prepare the bacterial suspension, cell pellets were collected from $10 \mathrm{ml}$ overnight culture broths of MR01 grown in LB by centrifugation at $7440 \times \mathrm{g}$ for $20 \mathrm{~min}$ and then resuspended in $10 \mathrm{ml}$ sodium phosphate buffer $(0.2 \mathrm{M}, \mathrm{pH} 7.0)$. Cell suspension was mixed with an equal volume of the sol solution in a sterile silicone cylindrical mold (syringe) with a diameter of $12 \mathrm{~mm}$. The gelation of the mixture occurred immediately, and the gel was then allowed to rest in order to complete polymerization and improve gel mechanical properties [23]. The aged gel was washed with sterile sodium phosphate buffer $(0.2 \mathrm{M}, \mathrm{pH} 7.0)$ in order to remove the non-immobilized cells and kept at $4^{\circ} \mathrm{C}$ in a sealed tube with a sterile phosphate buffer for further experiments.

\subsection{Influence of silica sol-gel immobilization and storage conditions on cell viability}

Immobilization of the cells in silica gel requires several chemical substances and chemical reactions causing a range of changes in the physico-chemical condition of the cell environment, such as temperature, $\mathrm{pH}$, viscosity and rigidity. Each imposes a significant stress on the bacterial cells and may lead to loss of cell viability and activity. One of the major limitations of 
cell immobilization techniques is maintaining cell viability during the immobilization approach and storage time. Consequently, plate count agar (PCA) as a standard method was used to assess the viability of cells [30] before and after the immobilization process, according to the procedure explained in detail in Analytical methods. Moreover, for the storage study, entrapped gel bacteria were stored in different sealed tubes containing phosphate buffer $(0.2 \mathrm{M}, \mathrm{pH}=7)$ and kept at $4^{\circ} \mathrm{C}$ and room temperature $\left(\simeq 25^{\circ} \mathrm{C}\right)$ until the tests were carried out. Encapsulated bacteria in each tube were evaluated for viability by the PCA method at specified time intervals.

\subsection{Successive fermentation batches}

Successive fermentation batches were established to evaluate long-term activity and reusability of silica gel-entrapped $P$. aeruginosa MR01 for production of biosurfactant as well as the assessment of mechanical stability of gel. One mold bacteria gel, pre-cultivated in LB medium overnight, was placed in a $250-\mathrm{ml}$ flask containing $50 \mathrm{ml}$ SOM medium including soybean oil. Fermentations were carried out at $30^{\circ} \mathrm{C}$ on a shaker at $200 \mathrm{rpm}$ for $168 \mathrm{~h}$. Subsequently, shaking was discontinued and supernatant was decanted to another container for further biosurfactant measurements. Silica gel entrapped cells remaining on the bottom of the flask were rinsed several times with sterile distilled water and buffer to remove any free cells, then transferred to a new 250-ml flask containing $50 \mathrm{ml}$ fresh SOM medium. Consecutive batch experiments were performed seven times in succession under the same conditions and following the procedures outlined above. Biosurfactant production efficiency (BPE) was calculated for each batch using the following equation:

$$
\operatorname{BPE}(\%)=\left([\mathrm{BS}]_{\mathrm{x}} /[\mathrm{BS}]_{1}\right) \times 100
$$

where $[B S]_{1}$ and $[B S]_{x}$ are the biosurfactant concentrations after the first and $x^{\text {th }}$ batches, respectively. 
Moreover, mechanical stability was measured for the mold silica gels against shear stress caused by stirring the flask. The percentage of the intact gels was estimated in each batch experiment by Equation 2:

Percent of intact gel $(\%)=\left(D_{1}-D_{x} / D_{1}\right) \times 100$

where $D_{1}$ and $D_{x}$ indicate diameters measured for one mold gel at the beginning of the first batch and at the end of $x^{\text {th }}$ batch, respectively.

\subsection{Analytical methods}

\subsubsection{Gas chromatography}

Fatty acid compositions were determined for all samples of fresh soybean oil, soybean oil refinery wastes and oils remaining at the end of cultivation. The AOCS method Ce 2-66 was used to prepare the fatty acid methyl esters (FAMEs) [31]. The FAME preparations were analyzed by GC-FID (6890 Agilent, USA) with a capillary column (BPX70, $120 \mathrm{~m} \times 250 \mu \mathrm{m} \times 0.25 \mathrm{~mm}$ ID) and helium as a carrier gas. The oven temperature was set to remain at $180^{\circ} \mathrm{C}$ for 30 min and then increased to $200^{\circ} \mathrm{C}$ at a rate of $1.5^{\circ} \mathrm{C} / \mathrm{min}$ and was then held at $200^{\circ} \mathrm{C}$ for $30 \mathrm{~min}$. The helium flow rate was $0.7 \mathrm{ml} / \mathrm{min}$. Sample injections were in split mode of $100: 1$ at $220^{\circ} \mathrm{C}$. The peaks were recognized, based on their retention times (RT) using standard FAMEs [1].

\subsubsection{Biosurfactant extraction and determination of concentrations}

Cell free supernatants were prepared after $168 \mathrm{~h}$ of cultivation of $P$. aeruginosa MR01 in SOM or alternative SOM mediums by centrifugation at $7440 \times \mathrm{g}$ for $20 \mathrm{~min}$. The cell-free supernatants were then acidified to $\mathrm{pH} 2.0$ with $6 \mathrm{~N} \mathrm{HCl}$ and kept at $4^{\circ} \mathrm{C}$ overnight until biosurfactant precipitates appeared. Biosurfactant pellets were harvested by centrifugation at $18000 \times \mathrm{g}$ at $4^{\circ} \mathrm{C}$ for 20 min and solvent extracted with ethyl acetate. Solvent was removed by evaporation and the extract was then weighed to determine the biosurfactant concentration [28]. 


\subsubsection{Biosurfactant purification}

Purification of crude biosurfactant was carried out using column chromatography according to published method [32] with slight modifications [33]. A mixture of $20 \mathrm{~g}$ silica gel 60 in chloroform was applied into glass column chromatography $(2 \times 40 \mathrm{~cm})$. Crude biosurfactant $(2 \mathrm{~g})$ was dissolved in $4 \mathrm{ml}$ chloroform and loaded onto the silica gel bed. The column was washed in a stepwise fashion with chloroform, chloroform:methanol 50:5, chloroform:methanol 50:50 to elude the neutral lipids, monorhamnolipids and dirhamnolipids from the silica gel bed, respectively. Purification was controlled by thin layer chromatography during all steps using silica gel plates by developing a solvent of chloroform/methanol/acetic acid (5:1:0.16, v/v/v) and a molish reagent as described by Lotfabad et al.[29]. Mono and di-rhamnolipid fractions were mixed to achieve a purified rhamnolipid mixture.

\subsubsection{Estimation of critical micelle concentration (CMC)}

Surface activity or capability of reducing the surface tension of solution is an inherent trait of surfactants. Accordingly, critical micelle concentration $(\mathrm{CMC})$ is defined as a concentration in which surfactant monomers begin to spontaneously associate into structured aggregates in solution and no further decrease in surface tension is detected. Herein, CMCs were determined for biosurfactants extracted and purified from each $168 \mathrm{~h}$ culture containing one of different carbon sources. CMCs shown by the break in the plot of the surface tension vs. logarithm of biosurfactant concentrations were estimated according to Lotfabad et al. [1].

\subsubsection{Mass spectrometry analysis}

To specify the type of congeners existing in rhamnolipid mixtures, electrospray ionization (ESI) mass spectra were recorded on a high-resolution Agilent Triple Quadrupole 6410 mass spectrometer. The ESI mass spectrum in the negative ion mode was acquired using a capillary voltage of $2.5 \mathrm{kV}$ and a fragmenting voltage of $135 \mathrm{~V}$. Drying gas (nitrogen) flow rate was 6.0 
$\mathrm{I} / \mathrm{min}$ and the gas was heated to $300^{\circ} \mathrm{C}$. ESI Mass spectrometry (ESI-MS) was acquired by massselecting the target ion using the quadrupole mass analyzer at $100 \circ \mathrm{C}$, collision induced dissociation using nitrogen in collision cell. Target ions with specified $\mathrm{m} / \mathrm{z}$ were selected according to the hypothetical pseudomolecular ions summarized by Déziel et al.[33,34] for rhamnolipid compounds. Each rhamnolipid mixture was dissolved in methanol:water $(9: 1, v / v)$, filtered $(0.22 \mathrm{~mm})$ and $10 \mu \mathrm{l}$ of this sample was introduced into the source at $0.35 \mathrm{ml} / \mathrm{min}$ with a nebulizer at $12 \mathrm{psi}$. The scanning mass range was from 50 to $2000 \mathrm{~m} / \mathrm{z}$. The contribution of each pseudomolecular ion with a specified $\mathrm{m} / \mathrm{z}$ was quantified by integrating the area under the extracted ion chromatograms (EIC) for that $\mathrm{m} / \mathrm{z}$.

\subsubsection{PCA method for cell viability measurements}

To determine the colony forming units (CFU) of free cells before immobilization, suspension of bacteria prepared for sol-gel was subjected to colony count agar. To prepare the bacterial suspension of immobilized cells, one mold gel of bacteria was disrupted by using a sterilized glass rod, homogenized in $1 \mathrm{ml} \mathrm{LB}$ medium with vortex and incubated at $30^{\circ} \mathrm{C}$ for 24 hours.

In order to find the CFU on agar plate, bacterial suspensions were serially diluted by sterile normal saline $(9 \mathrm{~g} / \mathrm{L}$ sodium chloride in distilled water) through a ten-fold dilution scheme. Then, $100 \mu \mathrm{l}$ of each dilution factor from $10^{\circ}$ to $10^{10}$ were spread separately on LB agar and incubated at $30^{\circ} \mathrm{C}$ for $24 \mathrm{~h}$. The total number of colony units formed was calculated only using plates containing $30-300$ colonies.

\subsubsection{Scanning electron microscopy}

The cell distribution patterns in gels were investigated by scanning electron microscopy (SEM) on MIRAIITESCAN SEM. Samples were prepared from the gel capsulated $P$. aeruginosa at three different stages: fresh gel immobilized cells which have not entered the fermentation process, gel entrapped cells collected after the first biosurfactant production batch in SOM 
medium containing soybean oil, and gel stored in phosphate buffer $\left(4{ }^{\circ} \mathrm{C}\right)$ for 365 days. The cell samples were fixed by glutaraldehyde $3 \%$ in phosphate buffer $(0.1 \mathrm{M}, \mathrm{pH}=7.2)$. After washing the cells with phosphate buffer for three times, dehydration was carried out by immersing the cells in a series of ethanol solutions of increasing concentrations until $100 \%$, water-free alcohol is reached [35].

\section{Results and discussion}

\subsection{Fatty acid patterns for oily carbon sources}

The gas chromatography profile of fatty acids (Table 1) reveals that two saturated fatty acids, palmitic (C16:0) and stearic acids (C18:0) and three unsaturated fatty acids, oleic (C18:1), linoleic (C18:2) and linolenic (C18:3) acids are the highest constituents of each oil source ( 95.7 \pm 0.9$)$. This result had previously been observed by Demirbaş [36] that stearic, palmitic, oleic, linoleic and linolenic acids are the most common fatty acids found in vegetable oils. Table 1 shows approximately the same profile for the main fatty acids existing in oily carbon sources. Consequently, MR01 cells are expected to form rhamnolipid products with analogous surface activities and similar distribution of rhamnolipid homologues in the presence of soybean oil alternatives. This will be discussed in the following section. 
Table 1.Fatty acid profiles of soybean oil and oil refinery wastes

\begin{tabular}{|c|c|c|c|c|c|c|c|c|c|c|}
\hline \multirow[b]{2}{*}{$\begin{array}{l}\text { Fatty acid } \\
\text { component }\end{array}$} & \multirow[b]{2}{*}{$\begin{array}{l}\text { Chemical } \\
\text { structure }\end{array}$} & \multirow[b]{2}{*}{$\begin{array}{c}\text { Molecular } \\
\text { formula }\end{array}$} & \multicolumn{2}{|c|}{ Soybean oil } & \multicolumn{2}{|c|}{ Acid oil } & \multicolumn{2}{|c|}{$\begin{array}{l}\text { Deodorizer } \\
\text { distillate }\end{array}$} & \multicolumn{2}{|c|}{ Soapstock } \\
\hline & & & $\begin{array}{l}\text { BF* } \\
\text { (\%) }\end{array}$ & $\begin{array}{l}\mathrm{AF}^{* *} \\
(\%)\end{array}$ & $\begin{array}{l}\mathrm{BF} \\
(\%)\end{array}$ & $\begin{array}{l}\mathrm{AF} \\
(\%)\end{array}$ & $\begin{array}{l}\mathrm{BF} \\
(\%)\end{array}$ & $\begin{array}{l}\mathrm{AF} \\
(\%)\end{array}$ & $\begin{array}{l}\mathrm{BF} \\
(\%)\end{array}$ & $\begin{array}{l}\text { AF } \\
(\%)\end{array}$ \\
\hline Caproic acid & C6:0 & $\mathrm{C}_{6} \mathrm{H}_{12} \mathrm{O}_{2}$ & 0 & 0 & 0 & 0 & 0 & 0 & 0 & 0 \\
\hline Caprylic acid & C8:0 & $\mathrm{C}_{8} \mathrm{H}_{16} \mathrm{O}_{2}$ & 0 & 0 & 0 & 0 & 0 & 0 & 0 & 0 \\
\hline Capric acid & C10:0 & $\mathrm{C}_{10} \mathrm{H}_{20} \mathrm{O}_{2}$ & 0 & 0 & 0 & 0.69 & 0 & 0 & 0 & 0 \\
\hline Lauric acid & $\mathrm{C} 12: 0$ & $\mathrm{C}_{12} \mathrm{H}_{24} \mathrm{O}_{2}$ & 0 & 0.1 & 0 & 0.13 & 0.44 & 0 & 0.02 & 0 \\
\hline Myristic acid & C14:0 & $\mathrm{C}_{14} \mathrm{H}_{28} \mathrm{O}_{2}$ & 0.1 & 0.14 & 0.11 & 0.23 & 0.71 & 0 & 0.1 & 0 \\
\hline Palmitic acid & $\mathrm{C} 16: 0$ & $\mathrm{C}_{16} \mathrm{H}_{32} \mathrm{O}_{2}$ & 11.74 & 10.7 & 10.07 & 8.23 & 26.08 & 19.38 & 13.05 & 7.2 \\
\hline Stearic acid & C18:0 & $\mathrm{C}_{18} \mathrm{H}_{36} \mathrm{O}_{2}$ & 4.39 & 5.09 & 3.48 & 6.89 & 6.56 & 10.16 & 4.59 & 3.25 \\
\hline Elaidic acid & $\begin{array}{l}\text { trans- } \\
\text { C18:1 }\end{array}$ & $\mathrm{C}_{18} \mathrm{H}_{34} \mathrm{O}_{2}$ & 0.66 & 0 & 0.48 & 0.64 & 0.41 & 0 & 0.66 & 0.35 \\
\hline Oleic acid & C18:1 & $\mathrm{C}_{18} \mathrm{H}_{34} \mathrm{O}_{2}$ & 22.7 & 24.95 & 32.54 & 37.98 & 30.1 & 32.44 & 35.6 & 41.8 \\
\hline trans-Linoleic acid & $\begin{array}{l}\text { trans- } \\
\text { C18:2 }\end{array}$ & $\mathrm{C}_{18} \mathrm{H}_{32} \mathrm{O}_{2}$ & 0.91 & 1 & 0.05 & 0 & 0.45 & 0.44 & 0.12 & 0 \\
\hline Linoleic acid & $\mathrm{C} 18: 2$ & $\mathrm{C}_{18} \mathrm{H}_{32} \mathrm{O}_{2}$ & 52.03 & 50.64 & 42.79 & 37.5 & 30.01 & 29.67 & 36.97 & 39.55 \\
\hline $\begin{array}{l}\text { trans-Linolenic } \\
\text { acid }\end{array}$ & $\begin{array}{l}\text { trans- } \\
\text { C18:3 }\end{array}$ & $\mathrm{C}_{18} \mathrm{H}_{30} \mathrm{O}_{2}$ & 1.7 & 1.1 & 0 & 0 & 0.32 & 1 & 0 & 0 \\
\hline Linolenic acid & C18:3 & $\mathrm{C}_{18} \mathrm{H}_{30} \mathrm{O}_{2}$ & 4.66 & 4.35 & 6.18 & 4.27 & 3.6 & 3.09 & 5.9 & 5.6 \\
\hline Erucic acid & C22:1 & $\mathrm{C}_{22} \mathrm{H}_{42} \mathrm{O}_{2}$ & 0.33 & 0 & 0.38 & 0 & 0.22 & 0 & 0.57 & 0.8 \\
\hline
\end{tabular}

* $\mathrm{BF}$ means before fermentation batch

** AF denotes after fermentation batch

\subsection{Measurement of production yield}

In order to compare the yields of biosurfactant production by $P$. aeruginosa MR01 in different media, including soybean oil and inexpensive refinery wastes, extracted biosurfactants were measured in crude and pure forms. This data was published in our previous study [2] and discussed extensively. In the present study, the quality of biosurfactants was evaluated with assessments organized under the following subtitles. 


\subsection{Critical micelle concentrations}

The impact of alternative carbon sources on surface activity of biosurfactants was investigated through the concentration of micelle formation. Plots given in Figure 1 show surface tension recorded in the presence of different biosurfactant concentrations (based on logarithmic scale) obtained from each culture containing one type of oil source. CMCs estimated for different biosurfactants are summarized in Table 2 . The measured $\mathrm{CMC}$ values display a similar range with little discrepancy. This may explain the propinquity in architecture of rhamnolipids existing in biosurfactants extracted from different cultures, including different oil sources, which is discussed in the following section. Due to different purities and rhamnolipid constituents, different CMC values within a range of 10 to $700 \mathrm{mg} / \mathrm{L}$ have been reported for rhamnolipid biosurfactants [37-43]. However, critical micelle concentration (CMC) is a measure of surfactant efficiency. Typical CMC values for chemical surfactants are less than $1 \%$ by weight (e.g., TRITON X-100 Surfactant has a CMC of $0.0130 \%$ ) $[33,44]$. A lower CMC indicates less surfactant is needed to saturate interfaces and form micelles. CMCs estimated for soybean oil alternatives were in a range of $0.0024-0.0036 \%$ which rivals that of chemical surfactants and demonstrates that a small amount of these biosurfactants can provide the desired micelle formations. And accordingly, the lower the consumption of surfactants, the more cost-effective the system is. However, rhamnolipid mixtures from different cultures could decrease the surface tension of double distilled water from $\simeq 72 \mathrm{mN} / \mathrm{m}$ to a range of $\simeq 27$ to $\simeq 32 \mathrm{mN} / \mathrm{m}$ which is comparable to those reported for synthetic surfactants. For example, silicon surfactants are highly effective surfactants in water and they lower aqueous surface tension to values of $20-30 \mathrm{mN} / \mathrm{m}$ [45]. Trisiloxane aqueous solutions also have minimum surface tension 20-25 mN/m [46]. 
Table 2. CMCs determined for rhamnolipid mixtures obtained from P.aeruginosa MR01 cultures contained different oil sources.

\begin{tabular}{|l|c|c|}
\hline Carbon sources & $\begin{array}{c}\text { CMC } \\
(\mathbf{m g} / \mathbf{l})\end{array}$ & $\begin{array}{c}\text { Surface tension, } \boldsymbol{V} \\
(\mathrm{mN} / \mathrm{m})\end{array}$ \\
\hline Soybean oil & 28.01 & 29.9 \\
\hline Soybean acid oil & 24.18 & 31.76 \\
\hline Soybean deodorizer distillate & 36.23 & 26.96 \\
\hline Soybean soapstock & 24.11 & 30.5 \\
\hline
\end{tabular}

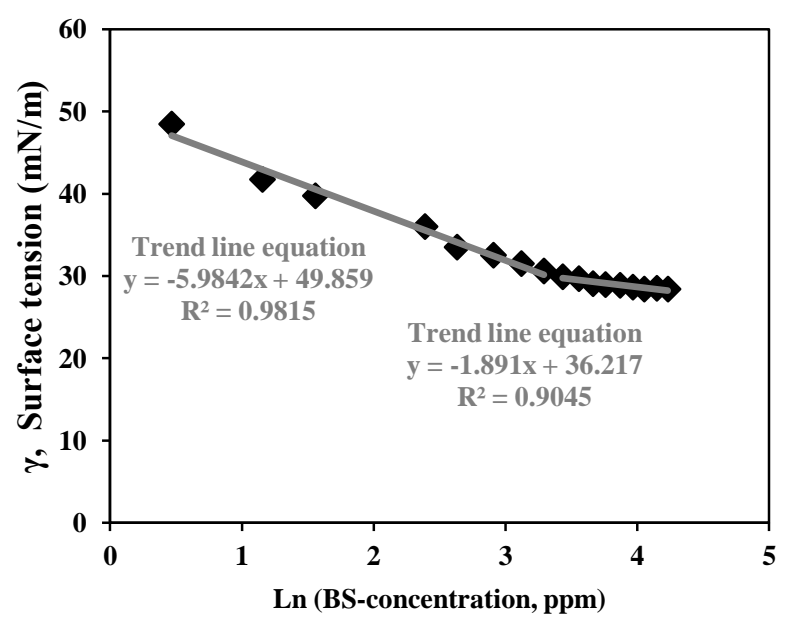

(a)

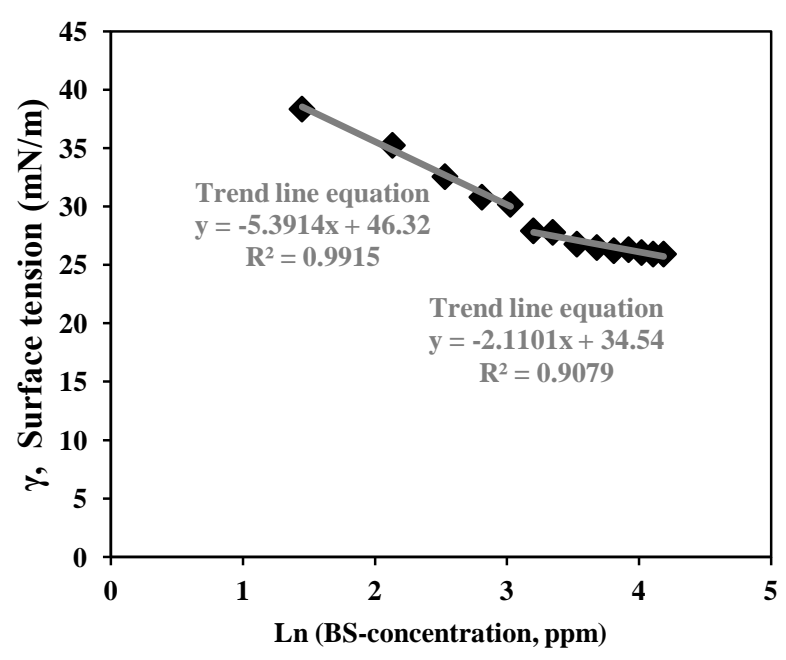

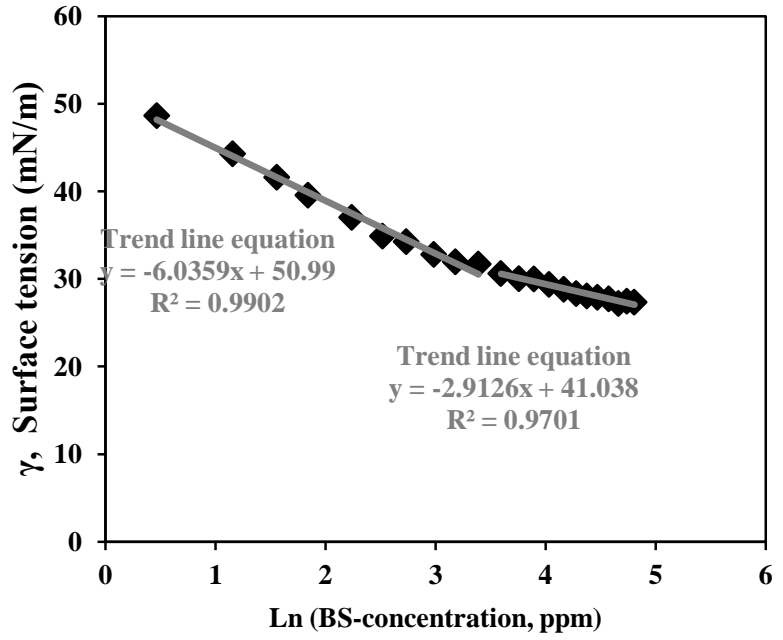

(b)

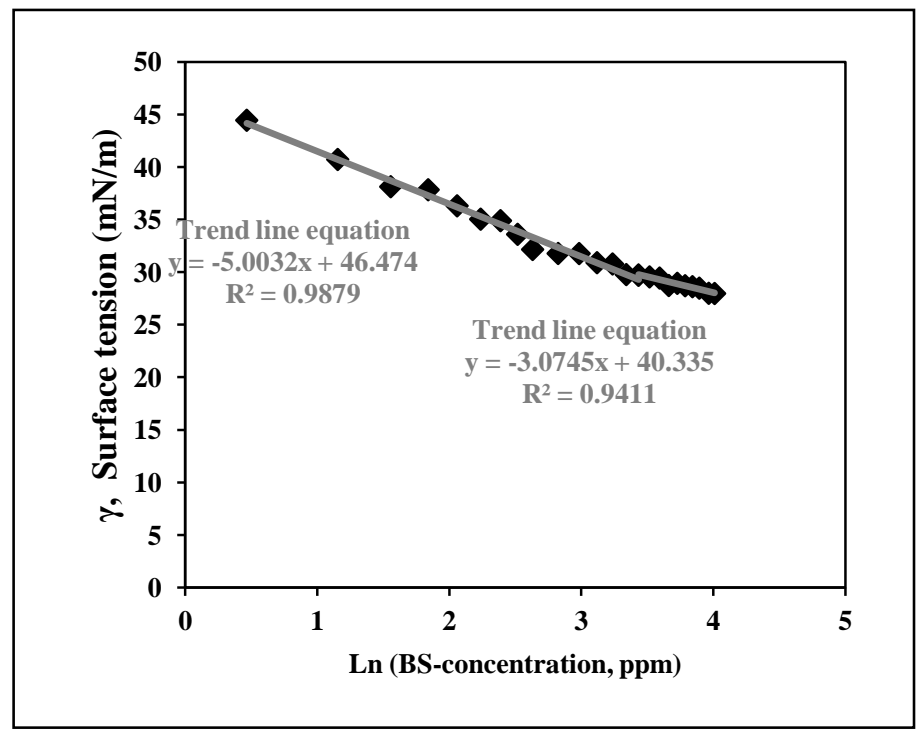

(d) 
Figure 1. Plots of surface tension against the logarithm of biosurfactant (BS) concentration aqueous solution. Biosurfactants are the purified rhamnolipid mixtures obtained from P.aeruginosa MR01 cultures contained soybean oil (a), acid oil (b), deodorizer distillate (c) and soapstock. different culture of at different concentrations. $\mathrm{CMC}$ is the intersection of two trend lines.

\subsection{Rhamnolipid homologues}

The structural analogy of rhamnolipids existing in biosurfactants purified from MR01 cultures with different oil sources, was recognized by mass spectrometry using the hypothetical molecular structures summarized by Déziel et al. [33,34]. ESI mass spectrums for the rhamnolipid mixtures produced by $P$. aeruginosa MR01 using different oil sources are shown in Figure 2. The main rhamnolipid homologues detected for each culture condition are displayed in Table 3 with relative abundance estimated from the area under the relative EIC. Observations show that the main rhamnolipid congeners are similar for all biosurfactants taken from different cultures with different carbon sources. Furthermore, standard deviations $(\sigma)$ and averages $(\mu)$ were calculated for relative abundance estimated for each congener existing in rhamnolipid mixtures as shown in Table 3. For Rha-C10, Rha-C10-C10 and Rha-Rha-C10-C10, approximately $50 \%$ of relative abundance values lie within 1 standard deviation from the mean $(\mu \pm 1 \sigma)$ and $100 \%$ of data, between $\mu-2 \sigma$ and $\mu+2 \sigma$. For Rha-C10-C8, Rha-C12:1-C10, Rha-RhaC12:1-C10 and Rha-Rha-C10-C12, approximately 75\% of relative abundance values fall within 1 standard deviation from the mean $(\mu \pm 1 \sigma)$ and $100 \%$ of data are between $\mu-2 \sigma$ and $\mu+2 \sigma$. In this way, considering a $6 \sigma$ range on a normal distribution plot, less than $5 \%(0.05)$ of the observations will be outside the $4 \sigma$ range. Therefore, with a 0.05 alpha level, low dispersion was found among the relative abundance estimated for each rhamnolipid homologue from each culture condition. This resemblance among types and abundance of rhamnolipid 
homologues existing in biosurfactants extracted from different cultures shows a similarity among the fatty acid profiles relevant to soybean oil and oil refinery wastes.

In each culture condition shown in Table 3, mono and di-rhamnolipids with a fatty acid chain of C10-C10 were predominant fractions of rhamnolipid homologues and make total relative abundance values $\simeq 85,84,83.1$ and $85.5 \%$ for culture containing soybean oil, acid oil, deodorizer distillate and soapstock, respectively. Typically, Rha-C10-C10 and Rha-Rha-C10-C10 are the main rhamnolipids produced by $P$. aeruginosa strains [47]. In addition, Table 3 shows that different oil carbon sources used in MR01 cultures caused rhamnolipid mixtures in which the proportion of Rha-C10-C10 relative to Rha-Rha-C10-C10 was more than one as well as the ratio of total mono-rhamnolipids/di-rhamnolipids $>1$.

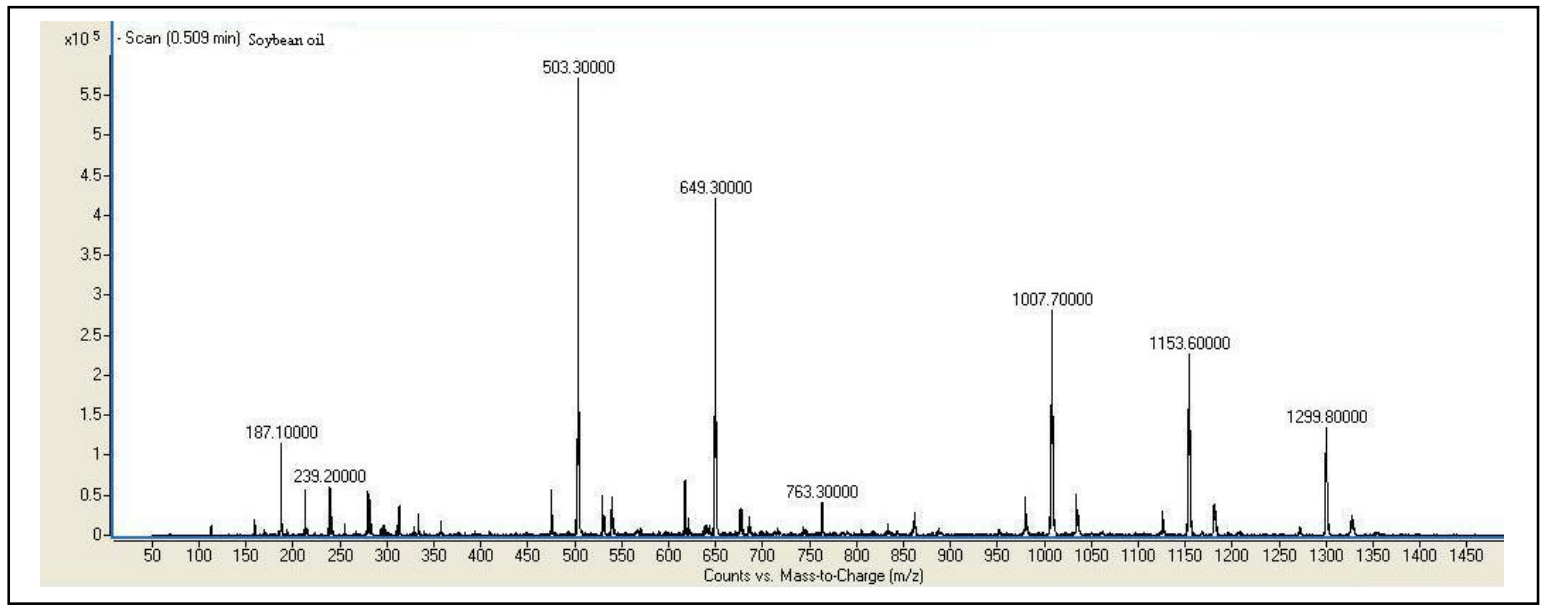

(a)

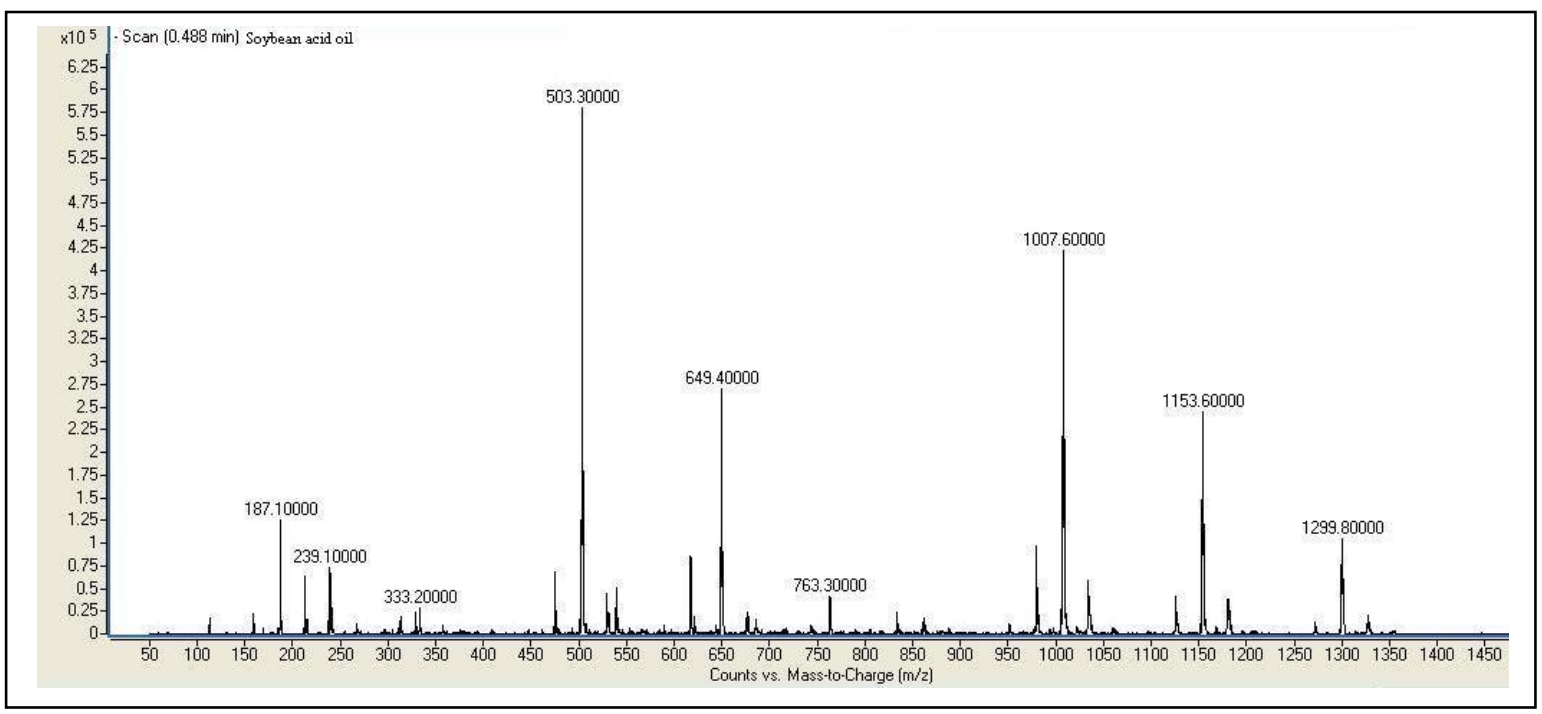


(b)

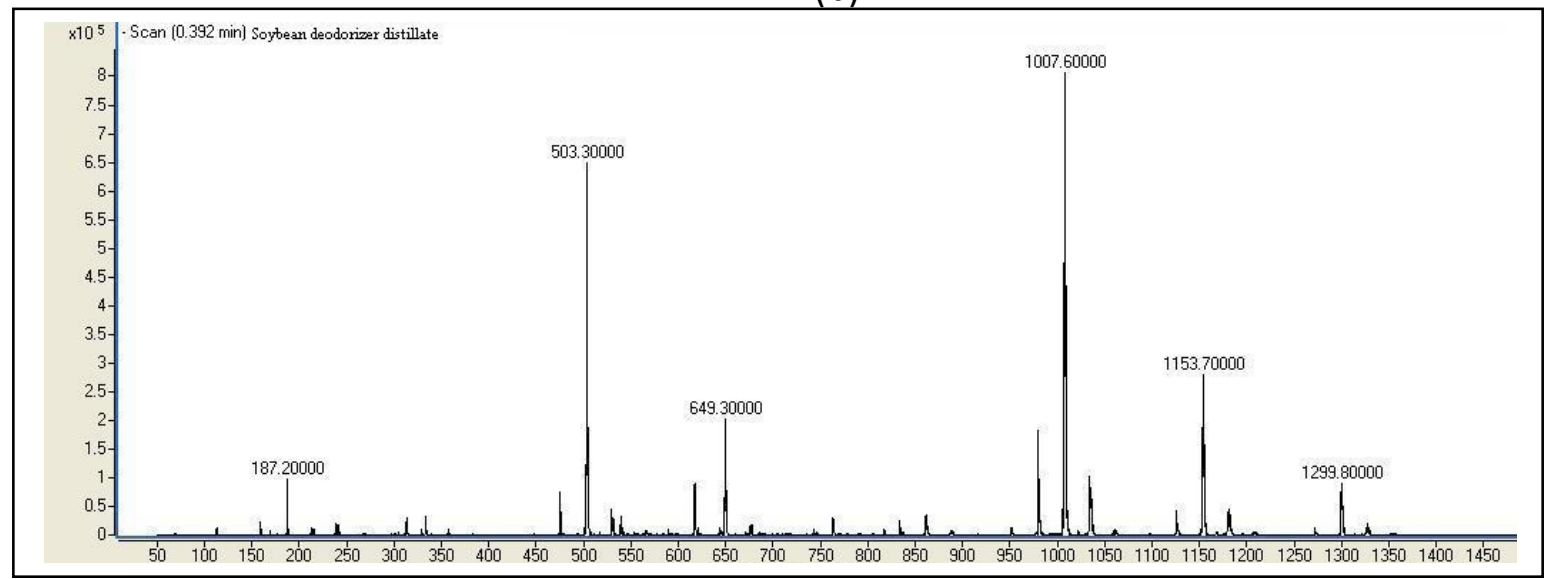

(c)

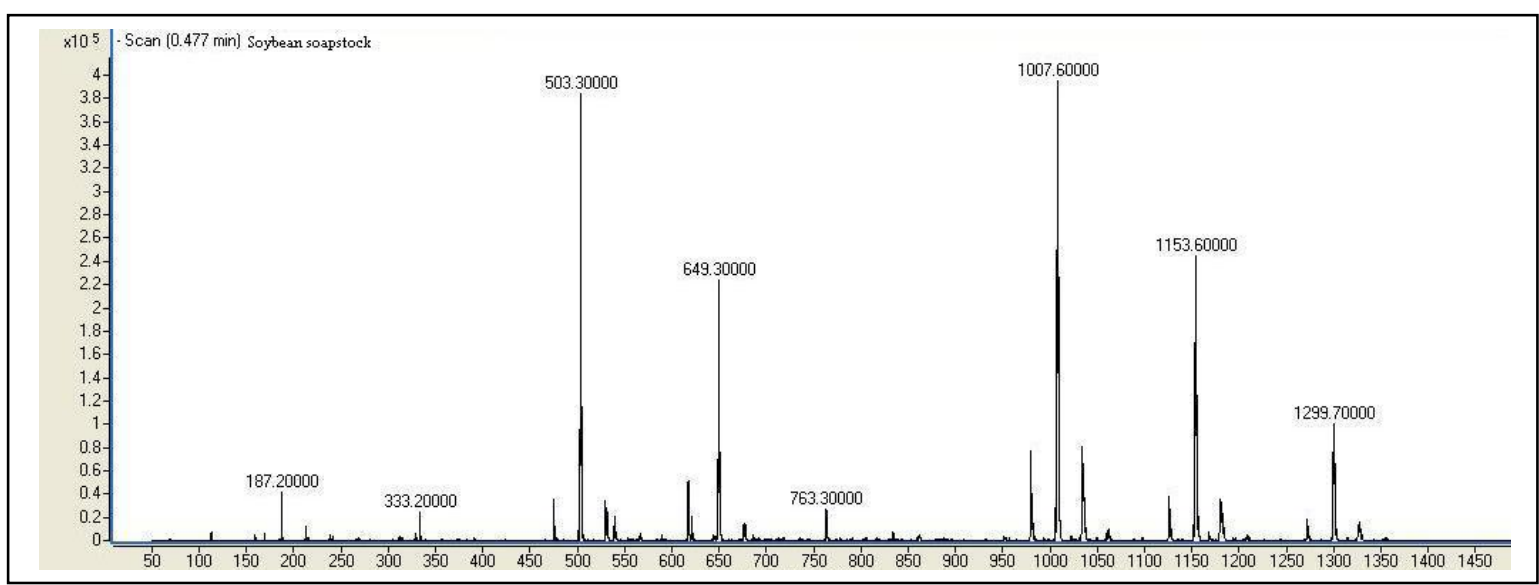

(d)

Figure 2. ESI mass spectrum for the rhamnolipids mixtures produced by $P$. aeruginosa MR01 using cultures contained (a) soybean oil, (b) acid oil, (c) deodorizer distillate and (d) soapstock. 
Table 3. Pseudomolecular ions and relative abundancs for rhamnolipid mixtures obtained from P.aeruginosa MR01 cultures with different oil sources.

\begin{tabular}{|c|c|c|c|c|c|c|}
\hline \multicolumn{7}{|c|}{ Relative abundance (\%) } \\
\hline Components & $\begin{array}{c}\text { Pseudomolecular } \\
\text { ion }(\mathrm{m} / \mathrm{z})\end{array}$ & $\begin{array}{c}\text { Soybean } \\
\text { oil }\end{array}$ & $\begin{array}{c}\text { Acid } \\
\text { oil }\end{array}$ & $\begin{array}{c}\text { Deodorizer } \\
\text { distillate }\end{array}$ & Soapstock & $\begin{array}{c}\text { Average } \\
\text { abundance }\end{array}$ \\
\hline Rha-C10 & 333 & 1.66 & 2.52 & 3.02 & 2.39 & $2.4 \pm 0.56$ \\
\hline Rha-C10-C8 & 475 & 3.92 & 5.63 & 6.86 & 3.78 & $5 \pm 1.47$ \\
\hline Rha-C10-C10 & 503 & 48.3 & 53.4 & 60.1 & 53.8 & $54 \pm 4.83$ \\
\hline Rha-C12:1-C10 & 529 & 3.49 & 3.84 & 3.81 & 4.47 & $3.9 \pm 0.41$ \\
\hline Rha-Rha-C10-C10 & 649 & 36.8 & 30.7 & 22.9 & 31.7 & $31 \pm 5.74$ \\
\hline Rha-Rha-C12:1-C10 & 675 & 2.4 & 1.74 & 1.3 & 1.6 & $1.8 \pm 0.46$ \\
\hline \multirow[t]{3}{*}{ Rha-Rha-C10-C12 } & 677 & 3.48 & 2.25 & 1.96 & 2.21 & $2.5 \pm 0.68$ \\
\hline & $\begin{array}{l}\text { Total Mono- } \\
\text { rhamnolipids }\end{array}$ & 57.3 & 65.4 & 73.8 & 64.5 & $65.2 \pm 6.75$ \\
\hline & $\begin{array}{l}\text { Total Di- } \\
\text { rhamnolipids }\end{array}$ & 42.7 & 34.6 & 26.2 & 35.5 & $34.7 \pm 6.75$ \\
\hline
\end{tabular}

\subsection{Influence of silica sol-gel immobilization and storage conditions on cell viability}

During the process of cell immobilization, the physico-chemical environment of the bacteria cells changes. Even though gel capsulated bacteria are kept at specified conditions, they may undergo changes. Consequently, to display the probable changes due to silica sol-gel immobilization and storage conditions, the most important feature of living cells, viability, was investigated. Cell viabilities were estimated for cell suspension before and after immobilization and monitored at specified time intervals during the storage in phosphate buffer at $4 \stackrel{\circ}{ } \mathrm{C}$ and 25 으 for 365 days. Viability of the $P$. aeruginosa cells was measured by counting the colony units formed on LB agar plates. Figure 3 shows that the count of $P$. aeruginosa MR01 cells decreased from the order of $\simeq 10^{9}$ to $\simeq 10^{8}$ while the silica sol-gel immobilization was performed. This $\simeq 10 \%$ reduction of cell viability may be the result of the presence of ethanol in TEOS derived matrices generated during the hydrolysis of precursors remaining after the 
evaporation step $[5,9,11,48]$. Moreover, $\mathrm{pH}$ variations, viscosity and rigidity increases due to gel formation, the aging process which causes shrinkage of the matrix and other changes occurring throughout the immobilization procedure may be among the stress factors harmful for cell activities [30]. However, further benefits of immobilized cells, particularly when entrapped in silica sol-gels $[17,49]$ are worth the drop in viability. Indeed, $\simeq 84 \%$ of viabilities of immobilized cells was retained after 365 days of immobilization and storage of the cells in phosphate buffer. This mere $\simeq 15 \%$ decrease in viability of stored cells relative to fresh silica immobilized MR01 cells is promising for long-term shelf life of immobilized bacteria. Usually such a reduction, more or less, occurs for viability of free cells when storing as -70 으 glycerol stocks or keeping in lyophilized form. Therefore, this demonstrates that the immobilized cells are able to withstand the stresses of both immobilization and storage relatively well.

Moreover, Figure 3 indicates that the trends of viability changes monitored for 365 days, similarly proceeded for $P$. aeruginosa MR01 entrapped by silica gel and kept at $4{ }^{\circ} \mathrm{C}$ and $25{ }^{\circ} \mathrm{C}$ in phosphate buffer. This suggests that the architecture of the cell wall of P. aeruginosa MR01 is such that cells are able to exhibit the same resistance to different storage temperatures after immobilization [11]. 


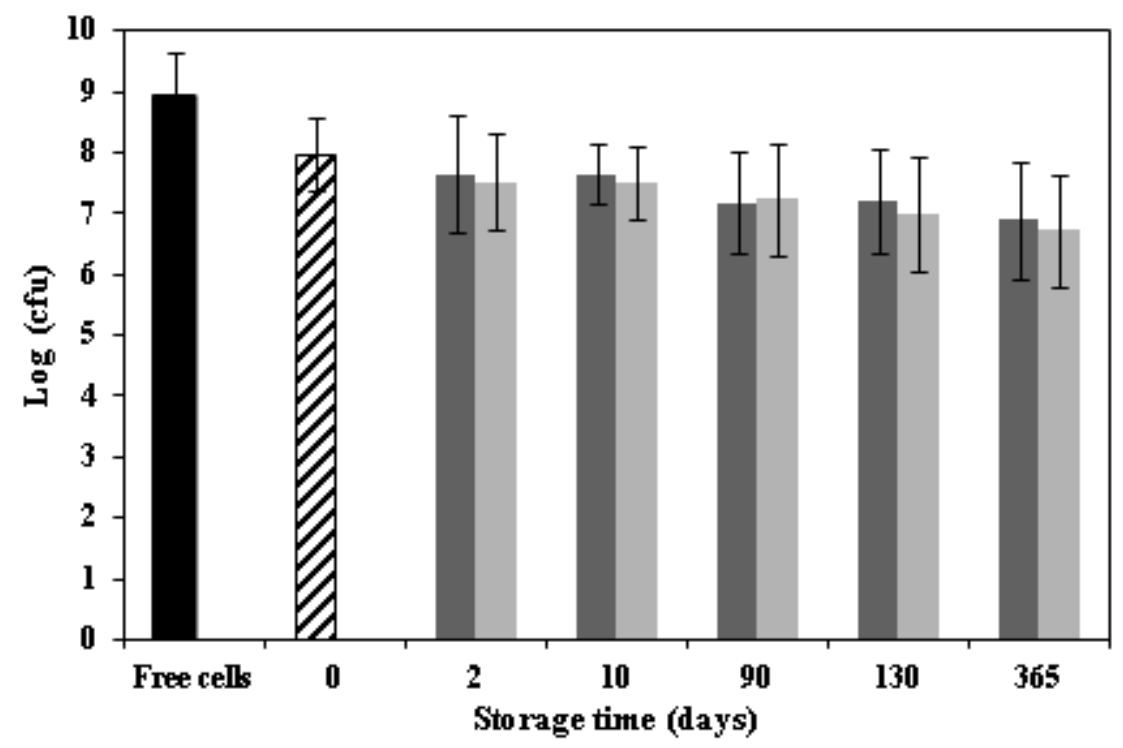

Figure 3. Cell viability for $P$. aeruginosa MR01 before $(\mathbf{\square})$ and immediately after (hachured square) immobilization and silica immobilized cells stored in phosphate buffer at 4 o $C$ (dark gray square) and 25 ㄷ (light gray square).

\subsection{Successive fermentation batches}

The first step for the feasibility study of applying the immobilized $P$. aeruginosa MR01 in flow reactors for production of biosurfactant, is to examine the reusability of these entrapped cells in consecutive fermentation batches. For this purpose, MR01 cells entrapped in silica matrices contributed in 7 successive batches to produce biosurfactant in SOM medium. During the down-time between each two consecutive batches, the gel immobilized cells were washed with sterile buffer to remove the free cells and other compounds on gel surfaces. Subsequently, fresh medium was replaced and a new fermentation batch restarted. Biosurfactant measurements taken after the completion of each batch, which required 7 days, showed that production efficiency was not only preserved during the three consecutive batches but also increased slightly (data shown in Fig 4). This may be attributed to the fact that the sol-gel technique leads to inorganic matrices possessing a high porosity $[11,49]$. The porous structure of silica gel $[23,48]$ allows the diffusion of the nutritional compounds from the 
medium to the interior of the silica gels and the release of the extracellular metabolites and biosurfactants out of the gels [4]. In this way, by exchanging fresh medium for the used medium in each batch, cell growth and reproduction are augmented and thus biosurfactant production increases. Immobilized cells continue this approach until the gels lose their strength after three batches and the percent of intact gels begins to reduce due to stirring shear stress. Thus, biosurfactant production decreases until the gel completely collapses. After 7 batches requiring a total of 49 days, $30 \%$ of a mold gel has remained intact and bacteria entrapped in this gel debris are viable and producible so that production efficiency of biosurfactant is $33.7 \%$. However, long-term mechanical stability of silica matrixes are responsible for the resistance to external forces during any application and thus aids the durable preservation of the cell viabilities and provides the reusability for the cells $[23,50]$. Durable and reusable immobilized cells are the suitable tools for flow fermentations in a packed-bed or fluidized-bed bioreactor [12].

\subsection{Scanning electron microscopy}

Distribution of immobilized MR01 cells throughout the silica gel was studied by scanning electron microscopy. SEM images were prepared for glutaraldehyde fixed gels immediately after immobilization (Fig. 5a), for collected gels from 7-day culture in SOM containing soybean oil (Fig. 5b), and for double distilled water rinsed buffer-kept gels at $4^{\circ} \mathrm{C}$ for 365 days (Fig. 5c). Figure 5 demonstrates the presence of MR01 cells in all examined gels.

Furthermore, Figure $5 b$ shows that the mass of the MR01 cells in silica gels increased after one batch cultivation in SOM medium in comparison to the cell mass in the freshly prepared gel containing cells. This supports the rise in biosurfactant produced after one batch cultivation shown in Figure 4. The SEM image (5b) confirms the ascending growth and reproduction of the MR01 cells. Figure $5 c$ indicates a decrease in the cell mass for immobilized cell gels stored for 
365 days in comparison to the ones assessed before storage. This reduction appears as a drop in cell count when viability measurements of different immobilized cell gels were carried out (Figure 3).

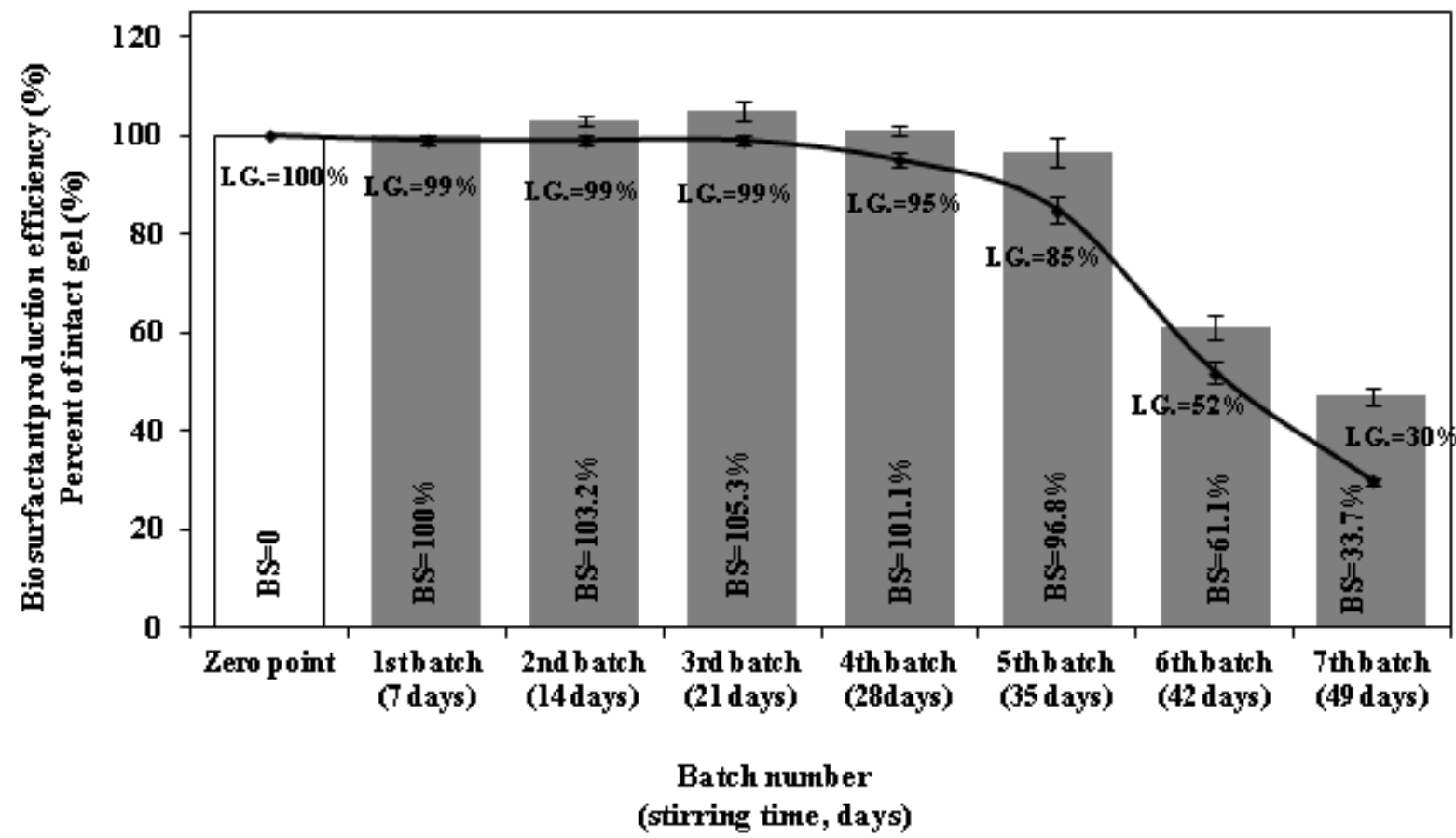

Figure 4. Preservation of biosurfactant producibility and percent of intact gel (I. G.) during the successive fermentation batches in SOM medium contained soybean oil included immobilized P.aeruginosa MR01. Column shows biosurfactant production efficiency and line indicates percent of intact gel at the end of each batch. 



Figure 5. The SEM photos of mold silica gel entrapped P.aeruginosa MR01 (a) immediately after gel immobilization (b) after first biosurfactant production batch in SOM medium contained soybean oil and (c) the silica mold gel cells stored at phosphate buffer $\left(4{ }^{\circ} \mathrm{C}\right)$ for 365 days.

\section{Conclusion}

Rhamnolipids, natural and eco-friendly surfactants which have shown many applications in a wide range of industries, are faced with economic challenges in order to be more widely commercialized. Therefore, the economic aspects of the rhamnolipid production process have been the main focus of this work. The present study attempts to demonstrate that $P$. aeruginosa MR01 can grow effectively in medium of soybean oil refinery wastes and produce rhamnolipids with similar surfactant features, such as surface activity and CMC and similar structural characteristics such as level and type of homologue contents, in comparison to products obtained through the use of costly soybean oil. Therefore, inexpensive waste carbon sources may efficiently replace more costly soybean oil to reduce the costs of biosurfactant production. In addition, the silica sol-gel method could adequately preserve the viability and biosurfactant production capability of the $P$. aeruginosa MR01 cells during the storage and 
successive fermentation batches. Consequently, silica sol-gel immobilization may be considered a second economical strategy towards cost effective production of biosurfactants.

\section{Acknowledgements}

The authors gratefully acknowledge the financial support granted by the National Institute of Genetic Engineering and Biotechnology [NIGEB, Grant No.430] as well as the Iran National Science Foundation [INSF, Grant No. 91003071] which made this research possible. They would also like to thank the Behshahr Industrial Company for providing the soybean oil wastes and other materials used in this study.

\section{References}

[1] T. B. Lotfabad, N. Ebadipour, and R. RoostaAzad, "Evaluation of a recycling bioreactor for biosurfactant production by Pseudomonas aeruginosaMR01 using soybean oil waste," J. Chem. Technol. Biotechnol., vol. 91, no. 5, pp. 1368-1377, May 2016. doi:10.1002/jctb.4733

[2] M. Partovi, T. B. Lotfabad, R. Roostaazad, M. Bahmaei, and S. Tayyebi, "Management of soybean oil refinery wastes through recycling them for producing biosurfactant using Pseudomonas aeruginosa MR01," World J Microbiol Biotechnol, vol. 29, no. 6, pp. 1039-1047, Jun. 2013. doi:10.1007/s11274-013-1267-7

[3] I. Chibata, T. Tosa, and T. Sato, "Immobilized aspartase-containing microbial cells: preparation and enzymatic properties," Appl Microbiol, vol. 27, no. 5, pp. 878-885, May 1974.

[4] M. V. Tuttolomondo, G. S. Alvarez, M. F. Desimone, and L. E. Diaz, "Removal of azo dyes from water by sol-gel immobilized Pseudomonas sp.," Journal of Environmental Chemical Engineering, vol. 2, no. 1, pp. 131-136, Mar. 2014. doi:10.1016/j.jece.2013.12.003

[5] M. R. Peralta-Pérez, M. A. Martínez-Trujillo, G. V. Nevárez-Moorillón, R. Pérez-Bedolla, and M. García-Rivero, "Immobilization of Aspergillus niger sp. in sol gel and its potential for production of xylanases," J Sol-Gel Sci Technol, vol. 57, no. 1, pp. 6-11, Sep. 2010. doi:10.1007/s10971-0102314-6

[6] Brinker, C.J. and Scherer, G. W(Eds), "Sol-gel science: : the physics and chemistry of sol-gel processing", Academic Press, Boston, 1990.

[7] J. Wiegmann, "The chemistry of silica. Solubility, polymerization, colloid and surface properties, and biochemistry. Von RALPH K. ILER. New York/Chichester/Brisbane/Toronto: John Wiley \& Sons," Acta Polym., vol. 31, no. 6, 1980. 
[8] A. Pannier, C. Oehm, A. R. Fischer, P. Werner, U. Soltmann, and H. Böttcher, "Biodegradation of fuel oxygenates by sol-gel immobilized bacteria Aquincola tertiaricarbonis L108," Enzyme and Microbial Technology, vol. 47, no. 6, pp. 291-296, Nov. 2010. doi:10.1016/j.enzmictec.2010.07.014

[9] A. Nieto, S. Areva, T. Wilson, R. Viitala, and M. Vallet-Regi, "Cell viability in a wet silica gel," Acta Biomater, vol. 5, no. 9, pp. 3478-3487, Nov. 2009. doi:10.1016/j.actbio.2009.05.033

[10] G.-H. Wang and L.-M. Zhang, "A biofriendly sol-gel route to new hybrid gels for enzyme encapsulation," J Sol-Gel Sci Technol, vol. 72, no. 1, pp. 85-91, Jun. 2014. doi:10.1007/s10971-0143429-y

[11] G. S. Alvarez, M. F. Desimone, and L. E. Diaz, "Immobilization of bacteria in silica matrices using citric acid in the sol-gel process," Appl Microbiol Biotechnol, vol. 73, no. 5, pp. 1059-1064, Sep. 2006. doi:10.1007/s00253-006-0580-6

[12] J.-P. Chen and Y.-S. Lin, "Decolorization of azo dye by immobilized Pseudomonas luteola entrapped in alginate-silicate sol-gel beads," Process Biochemistry, vol. 42, no. 6, pp. 934-942, Jun. 2007. doi:10.1016/j.procbio.2007.03.001

[13] S. Ramachandran, T. Coradin, P. K. Jain, and S. K. Verma, "Nostoc calcicola Immobilized in Silicacoated Calcium Alginate and Silica Gel for Applications in Heavy Metal Biosorption," Silicon, vol. 1, no. 4, pp. 215-223, Feb. 2010. doi:10.1007/s12633-009-9032-0

[14] G. Carturan, R. Campostrini, S. Diré, V. Scardi, and E. De Alteriis, "Inorganic gels for immobilization of biocatalysts: inclusion of invertase-active whole cells of yeast (saccharomyces cerevisiae) into thin layers of SiO2 gel deposited on glass sheets," Journal of Molecular Catalysis, vol. 57, no. 1, pp. L13-L16, Jan. 1989. doi:10.1016/0304-5102(89)80121-X

[15] C. F. Meunier, P. Dandoy, and B.-L. Su, "Encapsulation of cells within silica matrixes: Towards a new advance in the conception of living hybrid materials," J Colloid Interface Sci, vol. 342, no. 2, pp. 211-224, Feb. 2010. doi:10.1016/j.jcis.2009.10.050

[16] M. Blondeau and T. Coradin, "Living materials from sol-gel chemistry: current challenges and perspectives," J. Mater. Chem., vol. 22, no. 42, pp. 22335-22343, Oct. 2012. doi:10.1039/C2JM33647B

[17] N. Nassif, O. Bouvet, M. Noelle Rager, C. Roux, T. Coradin, and J. Livage, "Living bacteria in silica gels," Nat Mater, vol. 1, no. 1, pp. 42-44, Sep. 2002. doi:10.1038/nmat709

[18] M. F. Desimone, C. Hélary, G. Mosser, M.-M. Giraud-Guille, J. Livage, and T. Coradin, "Fibroblast encapsulation in hybrid silica-collagen hydrogels," J. Mater. Chem., vol. 20, no. 4, pp. 666-668, Jan. 2010. doi:10.1039/B921572G

[19] M. F. Desimone, M. C. D. Marzi, G. S. Alvarez, I. Mathov, L. E. Diaz, and E. L. Malchiodi, "Production of monoclonal antibodies from hybridoma cells immobilized in 3D sol-gel silica matrices," J. Mater. Chem., vol. 21, no. 36, pp. 13865-13872, Aug. 2011. doi:10.1039/C1JM11888A

[20] P. N. Catalano, N. S. Bourguignon, G. S. Alvarez, C. Libertun, L. E. Diaz, M. F. Desimone, and V. LuxLantos, "Sol-gel immobilized ovarian follicles: collaboration between two different cell types in hormone production and secretion," J. Mater. Chem., vol. 22, no. 23, pp. 11681-11687, May 2012. doi:10.1039/C2JM30888F

[21] P. Dandoy, C. F. Meunier, G. Leroux, V. Voisin, L. Giordano, N. Caron, C. Michiels, and B.-L. Su, "A Hybrid Assembly by Encapsulation of Human Cells within Mineralised Beads for Cell Therapy," PLOS ONE, vol. 8, no. 1, p. e54683, Jan. 2013. doi:10.1371/journal.pone.0054683

[22] M. F. Desimone, M. C. De Marzi, G. J. Copello, M. M. Fernández, E. L. Malchiodi, and L. E. Diaz, "Efficient preservation in a silicon oxide matrix of Escherichia coli, producer of recombinant proteins," Appl. Microbiol. Biotechnol., vol. 68, no. 6, pp. 747-752, Oct. 2005. doi:10.1007/s00253005-1912-7

[23] B. R. Mutlu, K. Hirschey, L. P. Wackett, and A. Aksan, "Long-term preservation of silica gelencapsulated bacterial biocatalysts by desiccation," J Sol-Gel Sci Technol, vol. 74, no. 3, pp. 823833, Mar. 2015. doi:10.1007/s10971-015-3690-8 
[24] J. F. T. Conroy, M. E. Power, J. Martin, B. Earp, B. Hosticka, C. E. Daitch, and P. M. Norris, "Cells in Sol-Gels I: A Cytocompatible Route for the Production of Macroporous Silica Gels," Journal of SolGel Science and Technology, vol. 18, no. 3, pp. 269-283, Aug. 2000. doi:10.1023/A:1008704208324

[25] D. J. Dickson and R. L. Ely, "Evaluation of encapsulation stress and the effect of additives on viability and photosynthetic activity of Synechocystis sp. PCC 6803 encapsulated in silica gel," Appl. Microbiol. Biotechnol., vol. 91, no. 6, pp. 1633-1646, Sep. 2011. doi:10.1007/s00253-0113517-7

[26] J. C. Harper, D. M. Lopez, E. C. Larkin, M. K. Economides, S. K. McIntyre, T. M. Alam, M. S. Tartis, M. Werner-Washburne, C. J. Brinker, S. M. Brozik, and D. R. Wheeler, "Encapsulation of S. cerevisiae in Poly(glycerol) Silicate Derived Matrices: Effect of Matrix Additives and Cell Metabolic Phase on Long-Term Viability and Rate of Gene Expression," Chem. Mater., vol. 23, no. 10, pp. 2555-2564, May 2011. doi:10.1021/cm103525u

[27] T. B. Lotfabad, M. Shourian, R. Roostaazad, A. R. Najafabadi, M. R. Adelzadeh, and K. A. Noghabi, "An efficient biosurfactant-producing bacterium Pseudomonas aeruginosa MR01, isolated from oil excavation areas in south of Iran," Colloids Surf B Biointerfaces, vol. 69, no. 2, pp. 183-193, Mar. 2009. doi:10.1016/j.colsurfb.2008.11.018

[28] N. Ebadipour, T. B. Lotfabad, S. Yaghmaei, and R. RoostaAzad, "Optimization of Low-Cost Biosurfactant Production From Agricultural Residues through the Response Surface Methodology," Prep. Biochem. Biotechnol., Mar. 2015. doi:10.1080/10826068.2014.979204

[29] T. B. Lotfabad, H. Abassi, R. Ahmadkhaniha, R. Roostaazad, F. Masoomi, H. S. Zahiri, G. Ahmadian, H. Vali, and K. A. Noghabi, "Structural characterization of a rhamnolipid-type biosurfactant produced by Pseudomonas aeruginosa MR01: Enhancement of di-rhamnolipid proportion using gamma irradiation," Colloids and Surfaces B: Biointerfaces, vol. 81, no. 2, pp. 397-405, Dec. 2010. doi:10.1016/j.colsurfb.2010.06.026

[30] G. S. Alvarez, M. L. Foglia, G. J. Copello, M. F. Desimone, and L. E. Diaz, "Effect of various parameters on viability and growth of bacteria immobilized in sol-gel-derived silica matrices," Appl. Microbiol. Biotechnol., vol. 82, no. 4, pp. 639-646, Mar. 2009. doi:10.1007/s00253-0081783-9

[31] V.C. Mehlenbacher,. T.H. Hopper, E.M. Sallee, W.E. Link "AOCS, 1997. Official methods and recommended practices of the American Oil Chemists' Society, 5 th ed.

[32] M. Sánchez, F. J. Aranda, M. J. Espuny, A. Marqués, J. A. Teruel, A. Manresa, and A. Ortiz, "Aggregation behaviour of a dirhamnolipid biosurfactant secreted by Pseudomonas aeruginosa in aqueous media," J Colloid Interface Sci, vol. 307, no. 1, pp. 246-253, Mar. 2007. doi:10.1016/j.jcis.2006.11.041

[33] E. Déziel, F. Lépine, D. Dennie, D. Boismenu, O. A. Mamer, and R. Villemur, "Liquid chromatography/mass spectrometry analysis of mixtures of rhamnolipids produced by Pseudomonas aeruginosa strain 57RP grown on mannitol or naphthalene," Biochim. Biophys. Acta, vol. 1440, no. 2-3, pp. 244-252, Sep. 1999.

[34] E. Déziel, F. Lépine, S. Milot, and R. Villemur, "Mass spectrometry monitoring of rhamnolipids from a growing culture of Pseudomonas aeruginosa strain 57RP," Biochim. Biophys. Acta, vol. 1485, no. 2-3, pp. 145-152, May 2000.

[35] J. J. Bozzola and L. D. Russell, Electron Microscopy: Principles and Techniques for Biologists. Jones \& Bartlett Learning, 1999.

[36] A. Demirbaş, "Biodiesel fuels from vegetable oils via catalytic and non-catalytic supercritical alcohol transesterifications and other methods: a survey," Energy Conversion and Management, no. 13, pp. 2093-2109, 2003. doi:10.1016/S0196-8904(02)00234-0

[37] E. Haba, M. J. Espuny, M. Busquets, and A. Manresa, "Screening and production of rhamnolipids by Pseudomonas aeruginosa 47T2 NCIB 40044 from waste frying oils," J. Appl. Microbiol., vol. 88, no. 3, pp. 379-387, Mar. 2000. 
[38] A. M. Abdel-Mawgoud, M. M. Aboulwafa, and N. A.-H. Hassouna, "Characterization of Rhamnolipid Produced by Pseudomonas aeruginosa Isolate Bs20," Appl Biochem Biotechnol, vol. 157, no. 2, pp. 329-345, May 2009. doi:10.1007/s12010-008-8285-1

[39] M. Nitschke, S. G. V. A. O. Costa, and J. Contiero, "Structure and Applications of a Rhamnolipid Surfactant Produced in Soybean Oil Waste," Appl Biochem Biotechnol, vol. 160, no. 7, pp. 20662074, Apr. 2010. doi:10.1007/s12010-009-8707-8

[40] S. N. R. L. Silva, C. B. B. Farias, R. D. Rufino, J. M. Luna, and L. A. Sarubbo, "Glycerol as substrate for the production of biosurfactant by Pseudomonas aeruginosa UCP0992," Colloids and Surfaces B: Biointerfaces, vol. 79, no. 1, pp. 174-183, Aug. 2010. doi:10.1016/j.colsurfb.2010.03.050

[41] M. Abouseoud, A. Yataghene, A. Amrane, and R. Maachi, "Effect of pH and salinity on the emulsifying capacity and naphthalene solubility of a biosurfactant produced by Pseudomonas fluorescens," J. Hazard. Mater., vol. 180, no. 1-3, pp. 131-136, Aug. 2010. doi:10.1016/j.jhazmat.2010.04.003

[42] W.-J. Xia, Z. Luo, H.-P. Dong, L. Yu, Q.-F. Cui, and Y.-Q. Bi, "Synthesis, Characterization, and Oil Recovery Application of Biosurfactant Produced by Indigenous Pseudomonas aeruginosa WJ-1 Using Waste Vegetable Oils," Appl Biochem Biotechnol, vol. 166, no. 5, pp. 1148-1166, Mar. 2012. doi:10.1007/s12010-011-9501-y

[43] M. M. Müller, J. H. Kügler, M. Henkel, M. Gerlitzki, B. Hörmann, M. Pöhnlein, C. Syldatk, and R. Hausmann, "Rhamnolipids-Next generation surfactants?," Journal of Biotechnology, vol. 162, no. 4, pp. 366-380, Dec. 2012. doi:10.1016/j.jbiotec.2012.05.022

[44] J. J. Williams, "B.1.II - Formulation of Carpet Cleaners A2 - Johansson, Ingegärd," in Handbook for Cleaning/Decontamination of Surfaces, P. Somasundaran, Ed. Amsterdam: Elsevier Science B.V., 2007.

[45] J.F. Richard (Ed), “Wiley: Chemistry and Technology of Surfactants”, Wiley \& Sons Ltd, United Kingdom ,2006

[46] N. M. Kovalchuk, A. Trybala, V. Starov, O. Matar, and N. Ivanova, "Fluoro- vs hydrocarbon surfactants: why do they differ in wetting performance?," Adv Colloid Interface Sci, vol. 210, pp. 65-71, Aug. 2014. doi:10.1016/j.cis.2014.04.003

[47] S. A. Monteiro, G. L. Sassaki, L. M. de Souza, J. A. Meira, J. M. de Araújo, D. A. Mitchell, L. P. Ramos, and N. Krieger, "Molecular and structural characterization of the biosurfactant produced by Pseudomonas aeruginosa DAUPE 614," Chem. Phys. Lipids, vol. 147, no. 1, pp. 1-13, May 2007. doi:10.1016/j.chemphyslip.2007.02.001

[48] J. Chen, Y. Xu, J. Xin, S. Li, C. Xia, and J. Cui, "Efficient immobilization of whole cells of Methylomonas sp. strain GYJ3 by sol-gel entrapment," Journal of Molecular Catalysis B: Enzymatic, vol. 30, no. 3-4, pp. 167-172, Aug. 2004. doi:10.1016/j.molcatb.2004.05.005

[49] M. F. Desimone, M. C. De Marzi, G. J. Copello, M. M. Fernández, F. L. Pieckenstain, E. L. Malchiodi, and L. E. Diaz, "Production of recombinant proteins by sol-gel immobilized Escherichia coli," Enzyme and Microbial Technology, vol. 40, no. 1, pp. 168-171, Dec. 2006. doi:10.1016/j.enzmictec.2005.11.052

[50] I. Krupa, T. Nedelčev, D. Račko, and I. Lacík, "Mechanical properties of silica hydrogels prepared and aged at physiological conditions: testing in the compression mode," J Sol-Gel Sci Technol, vol. 53, no. 1, pp. 107-114, Aug. 2009. doi:10.1007/s10971-009-2064-5 
TEOS Cell

Solution Suspension

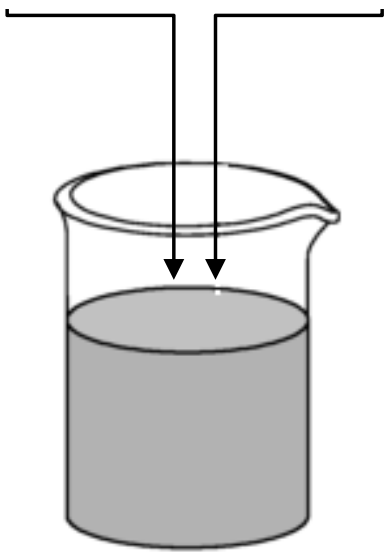

Sol-gel solution

Mass spectrum of purified biosurfactant

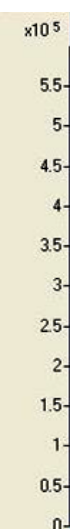

503.30000

187.10000

239.20000

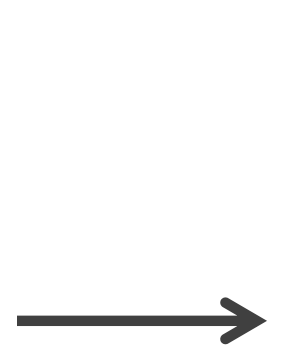

Molding

Gel entrapped cells

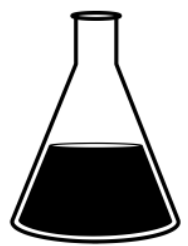

Crude

Biosurfactant

1007.70000

649.30000
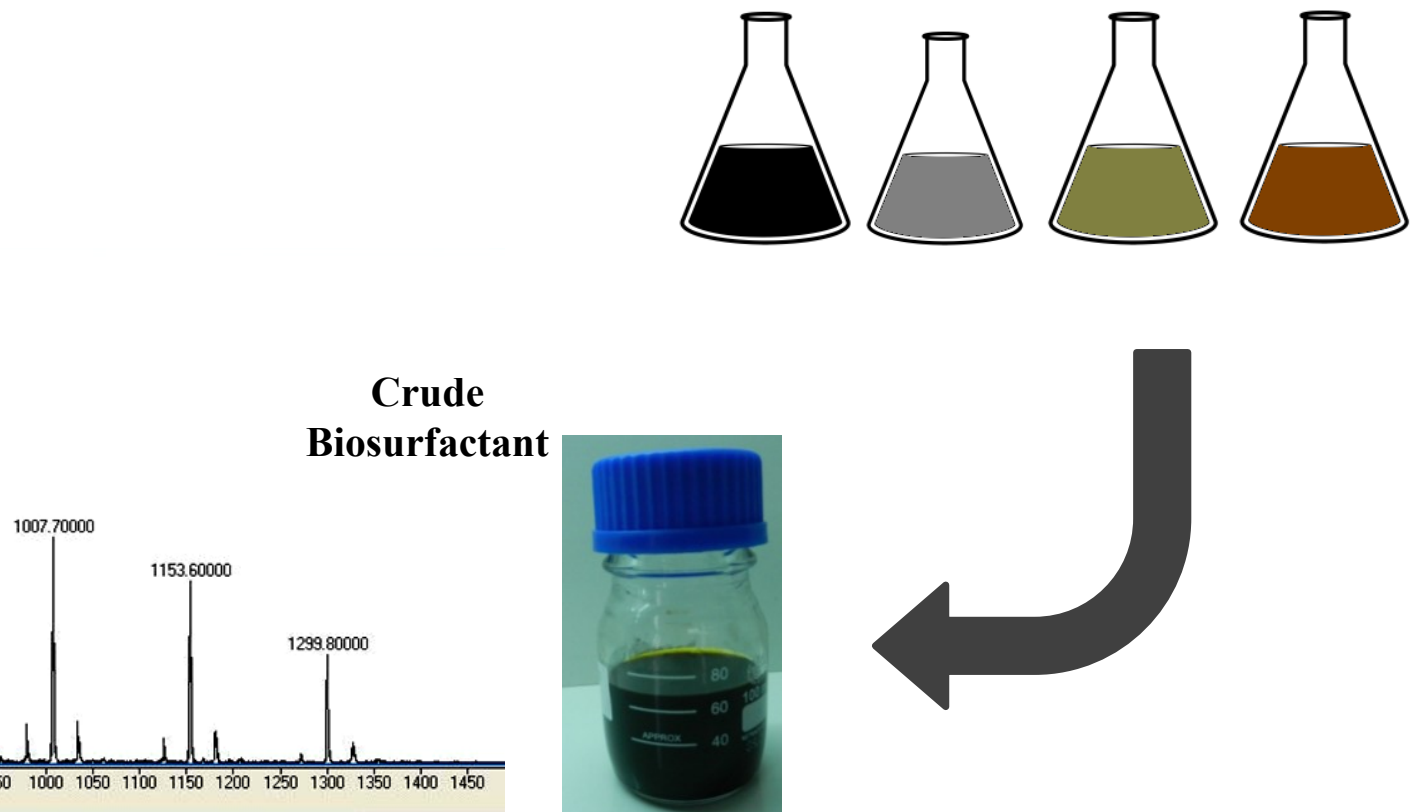